\title{
Faktor-Faktor yang Mempengaruhi Penyerapan Anggaran Belanja pada Satuan Kerja Perangkat Daerah Dengan Administrasi Sebagai Pemoderasi
}

\author{
Viki Ulandari ${ }^{1}$ \\ Fakultas Ekonomi dan Bisnis \\ Universitas Mataram, Indonesia
}

\author{
Akram $^{2}$ \\ Fakultas Ekonomi dan Bisnis \\ Universitas Mataram, Indonesia
}

\section{Budi Santoso ${ }^{3}$ \\ Fakultas Ekonomi dan Bisnis Universitas Mataram, Indonesia}

\begin{abstract}
Surel : vikiulandari9@gmail.com
ABSTRAK

Penelitian bertujuan memberikan bukti secara empiris mengenai pengaruh perencanaan, sumber daya manusia, dan pengadaan barang/jasa terhadap penyerapan anggaran belanja pada SKPD Kabupaten Sumbawa serta pengaruh administrasi dalam hubungan antara perencanaan, sumber daya manusia, dan pengadaan barang/jasa terhadap penyerapan anggaran belanja pada SKPD Kabupaten Sumbawa. Populasi penelitian adalah seluruh pegawai pada 29 SKPD Kabupaten Sumbawa. Hasil penelitian menunjukkan perencanaan berpengaruh negatif dan signifikan terhadap penyerapan anggaran. Sumber daya manusia dan pengadaan barang/jasa berpengaruh positif terhadap penyerapan anggaran. Sedangkan administrasi berpengaruh negatif terhadap hubungan perencanaan, sumber daya manusia dan pengadaan barang/jasa dengan penyerapan anggaran.
\end{abstract}

Kata Kunci: Penyerapan Anggaran; Perencanaan; Sumber Daya Manusia; Pengadaan Barang/jasa; Administrai.

\section{Factors Affecting Budget Absorption in Regional Work Units With Administration as Moderators}

\section{ABSTRACT}

This study aims to provide empirically the effect of planning, human resources, and procurement of goods / services on the absorption of the expenditure budget in the SKPD of Sumbawa Regency and the influence of administration in the relationship between planning, human resources, and procurement of goods / services on the absorption of the expenditure budget in SKPD Sumbawa regency. Population in this research is all employees at 29 SKPD Sumbawa Regency. The results showed that planning had a negative and significant effect on budget absorption. Human resources and the procurement of goods / services have a positive effect on budget absorption. Meanwhile, administration has a negative effect on the relationship between planning, human resources and the procurement of goods / services and budget absorption.

Keywords: Absorption Budget; Planning; human Resource; Procurement Of Goods / Services; Administration.

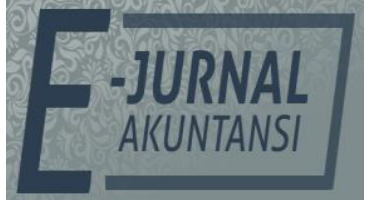

e-ISSN 2302-8556

Vol. 31 No. 6

Denpasar, Juni 2021

Hal. 1577-1591

DOI:

10.24843/EJA.2021.v31.i06.p18

PENGUTIPAN:

Ulandari, V., Akram, \&

Santoso, B. (2021). Faktor-

Faktor yang Mempengaruhi

Penyerapan Anggaran

Belanja pada Satuan Kerja

Perangkat Daerah Dengan

Administrasi Sebagai

Pemoderasi. E-Jurnal

Akuntansi, 31(6), 1577-1591

RIWAYAT ARTIKEL:

Artikel Masuk:

3 Mei 2021

Artikel Diterima:

23 Juni 2021

Artikel dapat diakses : https://ojs.unud.ac.id/index.php/Akuntansi/index 


\section{PENDAHULUAN}

Pengelolaan keuangan daerah yang ditetapkan setiap tahun dengan peraturan daerah diwujudkan dalam bentuk Anggaran Pendapatan dan Belanja Daerah (APBD). Seperti yang disebutkan dalam Permendagri Nomor 77 tahun 2020 bahwa segala bentuk Penerimaan Daerah maupun Pengeluaran Daerah harus dicatat dan dikelola dalam APBD. Dalam menjalani roda pemerintahan, tinggi rendahnya penyerapan anggaran dijadikan sebagai tingkat ukuran yang dapat mendeskripsikan seberapa jauh berjalannya target yang telah direncanakan oleh instansi pemerintah. Sehingga salah satu penentu keberhasilan suatu pemerintah menyelenggarakan pemerintahannya adalah penyerapan anggaran. Jika penyerapan anggaran rendah maka dapat dikatakan bahwa kualitas pemerintah kurang baik. Salah satu permasalahan dalam anggaran pemerintah adalah penyerapan anggaran yang cenderung rendah di awal tahun dan menumpuk di akhir tahun menyebabkan ketidakmerataan penyerapan anggaran (Suwarni \& Maruf, 2018). Terjadinya keterlambatan realisasi pada anggaran pemerintah daerah yang menumpuk di akhir tahun tentunya akan berdampak pada kualitas kinerja pemerintah.

Fenomena mengenai permasalahan penyerapan anggaran yang rendah pada awal sampai tengah tahun anggaran belanja ini juga terjadi pada Kabupaten/Kota di Provinsi Nusa Tenggara Barat dan berulang setiap tahunnya. Salah satu Kabupaten di Provinsi Nusa Tenggara Barat yang mengalami permasalahan penyerapan anggaran adalah Kabupaten Sumbawa. Menurut data yang termuat dalam Laporan Perekonomian Provinsi Nusa Tenggara Barat tahun 2019 yang di susun oleh Bank Indonesia, disana tertera bahwa penyerapan anggaran Kabupaten Sumbawa pada triwuan I sebesar 20,73 persen, triwulan II sebesar 42,81 persen, triwulan III sebesar 62,38 persen, dan triwulan IV sebebsar 97,07 persen. Dengan adanya fenomena tersebut tentunya akan menimbulkan permasalahan akibat penyerapan anggaran disepanjang tahun anggaran yang tidak merata. Karena penyerapan anggaran pada triwulan satu dan triwulan dua terbilang sangat lambat dan meningkat pada pertengahan triwulan ketiga serta puncaknya yaitu pada triwulan keempat dan relatif sama di setiap tahunnya. Sehingga sangat penting untuk diketahui apa saja faktor yang berpengaruh terhadap penyerapan anggaran di Kabupaten Sumbawa yang membuat penyerapan di awal tahun selalu rendah, dan di akhir tahun melonjak tinggi namun belum mencapai 100 persen.

Penelitian yang dilakukan oleh Thomas (2018) pada pemerintahan Kenya, menjelaskan bahwa proses penganggaran dan perencanaan merupakan sebuah penentu alokasi sumber daya di berbagai unit dalam sebuah organisasi, sehingga perencanaan akan mempengaruhi penyerapan anggaran. Penelitian yang dilakukan Cace et al., (2011) di Romania juga menyebutkan bahwa perencanaan salah satu penentu tingginya penyerapan anggaran, didukung hasil penelitian yang dilakukan oleh Zulaikah \& Burhany (2019) Hasni \& Basukianto (2016), Dewi et al (2017) dan Ramdhani \& Anisa (2017). Namun, berbeda dengan penelitian yang dilakukan oleh (Salwah, 2019) yang menyatakan sebaliknya bahwa perencanaan anggaran tidak berpengaruh terhadap penyerapan angggaran. Sehingga terdapat ketidakkonsistenan hasil untuk faktor perencanaan. 
Semakin tidak baik sumber daya manusia yang ada, maka akan memperlambat penyerapan anggaran, sebaliknya jika sumber daya manusia semakin baik maka akan mempercepat penyerapan anggaran sesuai jadwal yang telah ditetapkan (Hasni \& Basukianto, 2016). Penelitian yang dilakukan pada kementrian Kenya oleh Thomas (2018) menjelaskan bahwa Sumber daya manusia dapat memberikan kontribusi terhadap keberhasilan atau kegagalan suatu organisasi. Keterampilan, keahlian, dan pengalaman yang dimiliki staf merupakan aset berharga bagi organisasi. Beberapa penelitian sebelumnya juga menyatakan bahwa sumber daya manusia (SDM) berpengaruh pada penyerapan anggaran, yang dilakukan oleh Cace et al (2011), Putri (2014), dan Ramdhani \& Anisa (2017). Namun berbeda dengan penelitian yang dilakukan oleh (Rifai et al., 2016) dan Ramadhani \& Setiawan (2019) yang menyatakan sebaliknya bahwa sumber daya manusia tidak mempengaruhi penyerapan anggaran. Sehingga terdapat ketidakkonsistenan hasil untuk faktor sumber daya manusia.

Penelitian Tofani et al., (2020) menyatakan bahwa pengadaan barang dan jasa berpengaruh positif signifikan terhadap penyerapan anggaran. Hal ini karena salah satu upaya signifikan pemerintah untuk memenuhi kebutuhan masyarakat ialah melalui pengadaan barang dan jasa. Hasil serupa ditunjukkan pada penelitian yang dilakukan oleh Hasni \& Basukianto (2016) bahwa pengadaan barang dan jasa berpengaruh terhadap penyerapan anggaran. Namun hasil bertolak belakang pada penelitian yang dilakukan oleh Zulaikah \& Burhany, (2019) dan Sanjaya, (2018) yang menyatakan bahwa pengadaan barang dan jasa tidak berpengaruh terhadap penyerapan anggaran. Sehingga terdapat ketidakkonsistenan hasil untuk faktor pengadaan barang/jasa.

Adanya ketidakkonsistenan hasil penelitian mengenai pengaruh perencanaan, sumber daya manusia, dan pengadaan barang/jasa mengindikasikan bahwa terdapat faktor lain yang Mempengaruhi, sehingga mendorong peneliti untuk memasukkan administrasi sebagai variabel moderasi. Penelitian yang dilakukan oleh Yanuriza et al., (2019) menjelaskan bahwa administrasi berpengaruh signifikan terhadap penyerapan anggaran. Hal ini karena pencatatan administrasi sangatlah penting digunakan untuk bukti pencatatan, pengambilan keputusan dan pelaporan sehingga dapat mempengaruhi penyerapan anggaran dengan baik. Penelitian yang dilakukan Cace et al (2011) di Romania juga menyatakan bahwa administrasi merupakan salah satu faktor penentu tinggi nya penyerapan anggaran. Pernyataan tersebut didukung oleh hasil dari penelitian yang dilakukan oleh Tofani et al., (2020) dan Renoat \& Latupeirissa (2020). Penelitian yang dilakukan oleh Goddard \& Mkasiwa (2016) pada pemerintahan Tanzania juga menyatakan bahwa administrasi mempengaruhi penganggaran. Sehingga mengindikasikan bahwa administrasi dapat memperkuat atau memperlemah faktor-faktor yang Mempengaruhi penyerapan anggaran.

Penelitian yang membahas mengenai penyerapan anggaran belanja pada Satuan Kerja Perangkat Daerah sudah banyak dilakukan, namun belum ada penelitian terdahulu yang menggunakan administrasi sebagai moderasi antara perencanaan anggaran, sumber daya manusia, dan pengadaan barang/jasa terhadap penyerapan anggaran belanja. Selain itu, masih terdapat 
ketidakkonsistenan hasil penelitian atas faktor-faktor yang mempengaruhi penyerapan anggaran sehingga peneliti merasa perlu menguji ulang variabel ini kembali dengan menggunakan administrasi sebagai variabel moderasi dengan lokasi, jumlah sampel, dan periode waktu yang berbeda.

Penelitian ini dilakukan di Kabupaten Sumbawa karena belum pernah ada yang melakukan penelitian serupa serta adanya fenomena yang terjadi mengenai penyerapan anggaran belanja yang masih lambat dan tidak merata sampai akhir tahun. Sehingga peneliti ingin mengetahui apakah faktor perencanaan, sumber daya manusia, dan pengadaan barang/jasa mempengaruhi penyerapan anggaran belanja dengan administrasi sebagai variabel moderasi, agar SKPD di Pemerintahan Kabupaten Sumbawa dapat mengevaluasi hal-hal apa saja yang dapat ditingkatkan agar maksimal dalam melakukan penyerapan anggaran belanja.

Rumusan masalah dari penelitian ini adalah Apakah perencanaan, sumber daya manusia, dan pengadaan barang/jasa berpengaruh terhadap penyerapan anggaran belanja pada SKPD Kabupaten Sumbawa, Apakah administrasi memoderasi pengaruh perencanaan, sumber daya manusia, dan pengadaan barang/jasa terhadap penyerapan anggaran belanja pada SKPD Kabupaten Sumbawa. Selaras dengan rumusan maka tujuan dari penelitian ini adalah untuk menganalisis pengaruh perencanaan, sumber daya manusia, dan pengadaan barang/jasa terhadap penyerapan anggaran belanja pada SKPD Kabupaten Sumbawa untuk menganalisis administrasi dalam memoderasi pengaruh perencanaan, sumber daya manusia, dan pengadaan barang/jasa terhadap penyerapan anggaran belanja pada SKPD Kabupaten Sumbawa.

Pemerintah bertanggungjawab untuk melakukan serapan anggaran dengan baik, karena serapan anggaran akan berdampak langsung kepada masyarakat. Oleh karena itu, pemerintah tidak boleh mengutamakan kepentingan invidu. Teori stewardship dapat menggambarkan hal tersebut, karena menurut teori stewarship kepentingan organisasi lebih diutamakan daripada tujuan-tujuan individu. Tentunya dalam melaksanakan penyerapan anggaran pemerintah harus selalu melaporkan dan memberikan informasi sebagai bentuk pertanggungjawabannya kepada masyarakat. Pemberian sinyal atau informasi ini dapat digambarkan dengan teori signalling. Teori ini mengharuskan pemerintah untuk memberikan informasi kepada masyarakat sejauh mana pemerintah telah melakukan serapan anggaran. Selain itu, teori yang digunakan dalam penelitian ini adalah teori stakeholder yang mengharuskan pemerintah untuk memenuhi kebutuhan pemerintahan itu sendiri maupun stakeholder lainnya.

Jika pengelola anggaran dapat menyusun perencanaan dengan baik, maka program kerja/kegiatan dalam satu tahun anggaran akan berjalan dengan baik sehingga target penyerapan anggaran dapat tercapai (Iqbal, 2018). Namun sebaliknya apabila perencanaan kegiatan yang kurang matang akan berimplikasi pada pelaksanaan kegiatan yang tidak sesuai dengan perencanaannya. Hasil penelitian Ramdhani \& Anisa, (2017) tentang penyerapan anggaran pada Organisasi Perangkat Daerah Provinsi Banten menemukan bahwa faktor perencanaan anggaran berpengaruh positif signifikan terhadap penyerapan anggaran. Sesuai dengan hasil penelitian Iqbal, (2018), Renoat \& Latupeirissa, (2020), dan Salwah, (2019) yang menyatakan bahwa faktor perencanaan 
berpengaruh terhadap penyerapan anggaran. Berdasarkan penjelasan dan hasil penelitian terdahulu, maka dapat disimpulkan bahwa jika perencanaan meningkat maka penyerapan anggaran juga akan meningkat, sehingga dapat dirumuskan hipotesis sebagai berikut.

$\mathrm{H}_{1}$ : Perencanaan anggaran berpengaruh positif terhadap penyerapan anggaran belanja pada Satuan Kerja Perangkat Daerah.

Menurut Harahap et al., (2020) semakin baik kualitas sumber daya manusia suatu SKPD maka penyerapan anggarannya akan semakin baik, karena sumber daya manusianya sudah mengerti akan tugas pokok dan fungsinya. Sumber daya manusia dalam organisasi pemerintahan daerah harus selalu berada dalam proses pembelajaran agar potensi akal manusia dapat dikembangkan secara optimal (Anfujatin, 2016). Peranan aparatur pemerintah sangat menentukan keberhasilan organisasi pemerintah daerah dalam mendukung kinerja suatu instansi. Pegawai yang memiliki pemahaman yang rendah terhadap tugas dan fungsinya, serta hambatan yang ditemukan dalam pengolahan data juga akan berdampak pada efektifitas kinerja satuan kerja. Penyerapan anggaran SKPD akan baik apabila kualitas sumber daya manusia yang dimiliki satuan kerja juga baik. Penelitian yang dilakukan oleh Anfujatin (2016) tentang analisis faktor-faktor yang menyebabkan rendahnya penyerapan anggaran belanja pada SKPD Kabupaten Tuban menunjukkan bahwa sumber daya manusia mempengaruhi penyerapan anggaran. Terdapat pengaruh positif signifikan kompetensi sumber daya manusia (SDM) terhadap penyerapan anggaran. Hasil ini didukung oleh penelitian (Ramdhani \& Anisa, 2017) dan (Hasni \& Basukianto, 2016). Berdasarkan penjelasan dan hasil penelitian terdahulu, maka dapat disimpulkan bahwa jika sumber daya manusia meningkat maka penyerapan anggaran meningkat, sehingga dapat dirumuskan hipotesis sebagai berikut.

$\mathrm{H}_{2}$ : Sumber daya manusia berpengaruh positif terhadap penyerapan anggaran belanja pada Satuan Kerja Perangkat Daerah.

Dalam penelitian Alimuddin (2018) menjelaskan faktor pengadaan barang dan jasa mempunyai pengaruh yang signifikan terhadap penyerapan anggaran satuan kerja, faktor pengadaan barang dan jasa satuan kerja yang buruk dalam pelaksanaan kegiatan mempunyai kecenderungan memperlambat penyerapan anggaran satuan kerja. Ditambah permasalahan yang timbul seperti kebutuhan pegawai yang memiliki sertifikasi barang dan jasa dirasakan masih kurang, karena masih sedikitnya jumlah pegawai yang bersertifikat pengadaan barang dan jasa. Menurut Yanuriza et al., (2019) besarnya tanggung jawab dan resiko yang ditanggung oleh panitia pengadaan barang dan jasa karena tidak seimbangnya resiko pekerjaan dengan imbalan yang diterima juga memperlambat penyerapan anggaran. Penelitian yang dilakukan Setyawan (2016) dan Gagola (2016) juga menyatakan hal yang sama. Hal ini membuktikan bahwa pengadaan barang/jasa berpengaruh positif terhadap penyerapan anggaran. Berdasarkan penjelasan dan hasil penelitian terdahulu, maka dapat disimpulkan bahwa jika pengadaan barang dan jasa meningkat maka penyerapan anggaran juga akan meningkat, sehingga dapat dirumuskan hipotesis sebagai berikut.

$\mathrm{H}_{3}$ : Pengadaan barang/jasa berpengaruh positif terhadap penyerapan anggaran belanja pada Satuan Kerja Perangkat Daerah. 
Meskipun pemerintah daerah telah membuat perencanaan dengan baik namun masih terdapat administrasi yang belum terselesaikan, maka perencanaan yang telah dibuat tersebut tidak dapat direalisasi sebagaimana mestinya. Dalam penyerapan anggaran, administrasi berperan sangat penting mulai dari awal proses perencanaan sampai dengan penyerapan anggaran (Anfujatin, 2016). Penelitian yang dilakukan Putri (2014) menyatakan bahwa pencatatan administrasi berpengaruh terhadap penyerapan anggaran. Hal ini sejalan dengan penelitian yang dilakukan oleh Tofani et al., (2020) yang menyatakan bahwa administrasi dapat Mempengaruhi penyerapan anggaran. Oleh karena itu, dibutuhkan administrasi yang baik untuk merealisasisikan segala bentuk perencanaan yang telah disusun. Sehingga hipotesis keempat penelitian ini adalah sebagai berikut.

$\mathrm{H}_{4}$ : Administrasi memperkuat pengaruh perencanaan terhadap penyerapan anggaran belanja pada Satuan Kerja Perangkat Daerah.

Jika terjadi permasalahan administrasi dalam organisasi, maka meskipun kualitas SDM sudah sangat baik hal ini akan Mempengaruhi penyerapan anggaran karena pekerjaan staf pada pemerintah daerah pun akan terhambat. Sesuai dengan penelitian yang dilakukan oleh Tofani et al., (2020) yang menyatakan bahwa administrasi Mempengaruhi penyerapan anggaran dan dikung oleh penelitian yang dilakukan oleh (Renoat \& Latupeirissa, 2020). Sebaliknya, jika administrasi baik dan tepat waktu maka segala pekerjaan pun akan dapat terselesaikan dengan baik dan mempercepat penyerapan anggaran. Sehingga dapat ditarik kesimpulan bahwa kualitas sumber daya manusia yang baik dan dibarengi dengan administrasi dapat membantu mempercepat penyerapan anggaran belanja, maka hipotesis kelima penelitian ini adalah sebagai berikut.

$\mathrm{H}_{5}$ : Administrasi memperkuat pengaruh sumber daya manusia terhadap penyerapan anggaran belanja pada Satuan Kerja Perangkat Daerah.

Pengadaan barang dan jasa tidak akan berjalan dengan baik jika masih ada administrasi yang belum terselesaikan. Sejalan dengan penelitian yang dilakukan oleh Yanuriza et al., (2019), Tofani et al., (2020), dan Renoat \& Latupeirissa, (2020) yang menyatakan bahwa administrasi Mempengaruhi penyerapan anggaran. Misalnya proses penetapan panitia pengadaan dilakukan terlambat maka tentu seluruh rangkaian kegiatan akan mengalami keterlambatan dan menghambat penyerapan anggaran. Begitupun sebaliknya, jika dilaksanakan tepat waktu maka seluruh kegiatan dapat terlaksana dengan baik dan mempercepat penyerapan anggaran belanja. Hipotesis keenam dalam penelitian ini yaitu sebagai berikut.

$\mathrm{H}_{6}$ : Administrasi memperkuat pengaruh pengadaan barang/jasa terhadap penyerapan anggaran belanja pada Satuan Kerja Perangkat Daerah.

\section{METODE PENELITIAN}

Penelitian ini merupakan penelitian kuantitatif dan tergolong dalam penelitian asosiatif. Populasi pada penelitian ini adalah seluruh staf atau karyawan pada 29 SKPD Kabupaten Sumbawa yang terdiri dari Sekretariat, Inspektorat, Dinas, dan Badan berdasarkan data yang tertera dalam Peraturan Daerah Kabupaten Sumbawa Nomor 12 Tahun 2018. Dalam penelitian ini peneliti menggunakan teknik pengambilan sampel Purposive Sampling. Sampel penelitian ini adalah pegawai Satuan Kerja Perangkat Daerah (SKPD) Kabupaten Sumbawa yang 
dipilih berdasarkan kriteria-kriteria yang telah ditetapkan oleh peneliti. Adapun kriteria responden yang telah ditentukan oleh peneliti dalam penilitian ini sesuai dengan yang dijelaskan dalam Peraturan Pemerintah Republik Indonesia Nomor 12 Tahun 2019 adalah kepala SKPD, Kuasa Pengguna Anggaran (KPA), Pejabat Pelaksana Teknis Kegiatan (PPTK), Pejabat Penatausahaan Keuangan (PPK), dan Bendahara Pengeluaran. Jumlah sampel pada masing-masing Satuan Kerja Perangkat Daerah (SKPD) sebanyak 5 (lima) responden, sehingga total sampel dalam penelitian ini adalah 145 responden.

Dalam penelitian ini terdapat variabel eksogen, variabel endogen, dan variabel moderasi. Variabel endogen adalah Penyerapan Anggaran (PNRP), Variabel eksogen adalah Perencanaan (PRCN), Sumber Daya Manusia (SDM), Pengadaan Barang/Jasa (PBJ), dan Variabel moderator adalah Administrasi (ADM). Penyerapan anggaran diukur menggunakan indikator yang diadopsi dari Iqbal (2018) yaitu perbandingan realisasi dengan target, realisasi per-triwulan, dan konsistensi pelaksanaan. Perencanaan anggaran diukur dengan menggunakan indikator yang diadopsi dari penelitian Iqbal (2018) Visi misi, kesesuaian dengan kebutuhan, kesesuaian dengan aturan, ketepatan waktu, dan partisipatif. Sumber daya manusia diukur dengan menggunakan indikator yang diadopsi dari penelitian Ramadhani \& Setiawan (2019) kompetensi, kuantitas, penugasan rangkap, dan sertifikasi/pendidikan. Pengadaan barang dan jasa diukur dengan menggunakan indikator yang diadopsi dari penelitian Ramadhani \& Setiawan (2019), pelaksanaan, pelaksana, pemahaman peraturan, dan pemilihan penyedia barang dan jasa. Administrasi diukur dengan menggunakan indikator yang diadopsi dari penelitian Anfujatin (2016) penerbitan SK dan Revisi DPA. Pengukuran variabel dalam penelitian ini menggunakan skala likert dengan lima alternatif jawaban sebagai berikut, Sangat Tidak Setuju (STS) diberi skor $=1$; Tidak Setuju (TS) diberi skor = 2; Netral $(\mathrm{N})$ diberi skor $=3$; Setuju $(\mathrm{S})$ diberi skor $=4$; Sangat Setuju (SS) diberi skor $=5$.

Jenis data dalam penelitian ini adalah data subjek. Sumber data dalam penelitian ini adalah data primer. Teknik Pengumpulan data yang dilakukan dalam penelitian ini menggunakan kuesioner dengan cara membagi angket kuesioner yang berisi pertanyaan yang sudah disiapkan alternatif jawabannya. Teknik pengumpulan data yang dilakukan dalam penelitian ini menggunakan kuesioner terstruktur terdiri dari pertanyaan tertutup berupa suatu pernyataan yang diberikan kepada responden untuk diisi berdasarkan pendapat masingmasing.

Data yang telah dikumpulkan selanjutnya dianalisis menggunakan analisis statistik deskriptif dan Analisis PLS-SEM. Statistik deskriptif merupakan statistik yang menggambarkan fenomena atau karakteristik dari data (Hartono, 2014:195). Dalam penelitian ini metode analisis data yang digunakan adalah metode SEMPLS dengan bantuan program Smart PLS versi 3.0. Berdasarkan Ghozali \& Latan (2015:47) tahapan analisis menggunakan PLS-SEM harus melalui lima tahapan dan setiap tahapan akan berpengaruh terhadap tahapan selanjutnya. Tahapan analisis adalah konseptualisasi model, menentukan metode analisis algoritma, menentukan metode resampling, menggambar diagram jalur, dan evaluasi model. 


\section{HASIL DAN PEMBAHASAN}

Validitas konvergen berhubungan dengan prinsip bahwa pengukur-pengukur (manifest variabel) dari suatu konstruk seharusnya berkorelasi tinggi. Uji ini dilihat dari nilai loading factor untuk tiap indikator konstruk. Rentang nilai loading factor yaitu 0.6 sampai 0.7 dianggap cukup. (Ghozali \& Latan, 2015:74). Hasil pengujian convergent validity dalam penelitian ini yaitu sebagai berikut.

\section{Tabel 1. Outer Loading}

\begin{tabular}{|c|c|c|c|c|c|c|c|c|}
\hline & ADM & $\begin{array}{l}\text { Efek } \\
\text { Moderasi } \\
1\end{array}$ & $\begin{array}{l}\text { Efek } \\
\text { Moderasi } \\
2\end{array}$ & $\begin{array}{l}\text { Efek } \\
\text { Moderasi } \\
3\end{array}$ & PBJ & PNRP & PRCN & SDM \\
\hline ADM1 & 0,982 & & & & & & & \\
\hline ADM2 & 0,695 & & & & & & & \\
\hline $\mathrm{PBJ}^{*} \mathrm{ADM}$ & & & & 1,199 & & & & \\
\hline PBJ1 & & & & & 0,831 & & & \\
\hline PBJ2 & & & & & 0,746 & & & \\
\hline РBJ3 & & & & & 0,805 & & & \\
\hline PBJ4 & & & & & 0,760 & & & \\
\hline PNRP1 & & & & & & 0,718 & & \\
\hline PNRP2 & & & & & & 0,868 & & \\
\hline PNRP3 & & & & & & 0,862 & & \\
\hline $\mathrm{PRCN}^{*} \mathrm{AD}$ & & 1,070 & & & & & & \\
\hline M & & & & & & & & \\
\hline PRCN1 & & & & & & & 0,649 & \\
\hline PRCN2 & & & & & & & 0,709 & \\
\hline PRCN3 & & & & & & & 0,775 & \\
\hline PRCN4 & & & & & & & 0,612 & \\
\hline PRCN5 & & & & & & & 0,834 & \\
\hline $\mathrm{SDM}^{*} \mathrm{ADM}$ & & & 1,030 & & & & & \\
\hline SDM1 & & & & & & & & 0,684 \\
\hline SDM2 & & & & & & & & 0,675 \\
\hline SDM3 & & & & & & & & 0,805 \\
\hline SDM4 & & & & & & & & 0,780 \\
\hline
\end{tabular}

Sumber: Data primer diolah, 2021

Analisis statistik deskriptif digunakan untuk membandingkan data sampel (Sugiyono, 2013:207). Hasil analisis statistik deskriptif menunjukkan nilai perencaan terendah adalah 3.000 dan nilai tertinggi adalah 5.000 dengan rata-rata 4.662 dan standar deviasi sebesar 0,473, ini menunjukkan bahwa variabel perencanaan memiliki sebaran yang kecil karena standar deviasi lebih kecil dari nilai rata-rata. Nilai terendah sumber daya manusia adalah 2.000 dan nilai tertinggi 5.0000, dengan rata-rata sebesar 3.987 dan standar deviasi sebesar 0.901, ini menunjukkan bahwa variabel sumber daya manusia memiliki sebaran yang kecil karena standar deviasi lebih kecil dari nilai rata-rata.

Nilai terendah pengadaan barang/jasa sebesar 2.000 dan nilai tertinggi adalah 5.000, dengan rata-rata sebesar 4.550 dan standar deviasi sebesar 0,497, ini menunjukkan bahwa variabel pengadaan barang/jasa memiliki sebaran yang kecil karena standar deviasi lebih kecil dari nilai rata-rata. Nilai terendah administrasi adalah 2.000 dan nilai tertinggi sebesar 5.000, dengan rata-rata 3.975 dan standar deviasi sebesar 0,632, ini menunjukkan bahwa variabel administrasi memiliki sebaran yang kecil karena standar deviasi lebih kecil dari nilai rata-rata. 
Nilai terendah penyerapan anggaran adalah 2.000 dan tertinggi sebesar 5.000, dengan rata-rata sebesar 4.162 dan standar deviasi 0,459, ini menunjukkan bahwa variabel penyerapan anggaran memiliki sebaran yang kecil karena standar deviasi lebih kecil dari nilai rata-rata.

Validitas diskriminan berhubungan dengan prinsip bahwa pengukurpengukur (manifest variabel) konstruk yang berbeda seharusnya tidak berkorelasi dengan tinggi. Discriminant Validity dapat dievaluasi dengan melihat nilai cross loading yaitu loading indikator ke konstruk yang diukur lebih besar dari pada loading ke konstruk lain atau dengan melihat akar kuadrat Average Variance Extracted (AVE) lebih besar dari korelasi antar konstruk. (Ghozali \& Latan, 2015:74). Hasil pengujian validitas diskriminan sebagai berikut.

Tabel 2. Cross Loading

\begin{tabular}{|c|c|c|c|c|c|c|c|c|}
\hline & $\mathrm{ADM}$ & $\begin{array}{l}\text { Efek } \\
\text { Moderasi } \\
1\end{array}$ & $\begin{array}{l}\text { Efek } \\
\text { Moderasi } \\
2\end{array}$ & $\begin{array}{l}\text { Efek } \\
\text { Moderasi } \\
3\end{array}$ & PBJ & PNRP & PRCN & SDM \\
\hline ADM1 & 0,982 & 0,220 & 0,011 & 0,085 & 0,150 & 0,342 & 0,176 & 0,152 \\
\hline ADM2 & 0,695 & 0,123 & 0,040 & 0,041 & 0,058 & 0,089 & 0,077 & 0,042 \\
\hline $\mathrm{PBJ}^{*} \mathrm{ADM}$ & 0,082 & 0,851 & 0,601 & 1,000 & $-0,107$ & 0,018 & 0,003 & $-0,043$ \\
\hline PBJ1 & 0,087 & $-0,056$ & $-0,117$ & $-0,120$ & 0,831 & 0,553 & 0,636 & 0,376 \\
\hline PBJ2 & 0,159 & $-0,007$ & 0,017 & $-0,054$ & 0,746 & 0,417 & 0,601 & 0,297 \\
\hline PBJ3 & 0,123 & 0,051 & $-0,028$ & 0,000 & 0,805 & 0,358 & 0,639 & 0,125 \\
\hline PBJ4 & 0,091 & 0,041 & $-0,007$ & $-0,132$ & 0,766 & 0,482 & 0,439 & 0,186 \\
\hline PNRP1 & 0,095 & 0,106 & 0,057 & 0,018 & 0,430 & 0,718 & 0,304 & 0,201 \\
\hline PNRP2 & 0,310 & 0,058 & 0,017 & 0,025 & 0,490 & 0,868 & 0,468 & 0,356 \\
\hline PNRP3 & 0,321 & 0,127 & $-0,169$ & 0,004 & 0,521 & 0,862 & 0,412 & 0,428 \\
\hline $\mathrm{PRCN}^{*} \mathrm{ADM}$ & 0,217 & 1,000 & 0,510 & 0,851 & 0,003 & 0,117 & 0,066 & 0,111 \\
\hline PRCN1 & 0,209 & $-0,078$ & 0,010 & $-0,089$ & 0,487 & 0,245 & 0,649 & 0,083 \\
\hline PRCN2 & 0,114 & 0,078 & 0,118 & 0,083 & 0,615 & 0,380 & 0,709 & 0,148 \\
\hline PRCN3 & 0,143 & 0,023 & 0,071 & 0,001 & 0,563 & 0,342 & 0,775 & 0,264 \\
\hline PRCN4 & 0,054 & 0,095 & 0,038 & $-0,018$ & 0,323 & 0,357 & 0,612 & 0,316 \\
\hline PRCN5 & 0,118 & 0,076 & 0,147 & $-0,000$ & 0,622 & 0,400 & 0,834 & 0,404 \\
\hline $\mathrm{SDM}^{*} \mathrm{ADM}$ & 0,018 & 0,510 & 1,000 & 0,601 & $-0,050$ & $-0,054$ & 0,116 & 0,098 \\
\hline SDM1 & 0,107 & 0,107 & 0,045 & 0,029 & 0,017 & 0,311 & 0,052 & 0,684 \\
\hline SDM2 & 0,046 & 0,120 & 0,048 & $-0,008$ & 0,007 & 0,155 & 0,109 & 0,675 \\
\hline SDM3 & 0,201 & 0,134 & 0,134 & $-0,001$ & 0,505 & 0,372 & 0,459 & 0,805 \\
\hline SDM4 & 0,006 & $-0,018$ & 0.040 & $-0,140$ & 0,276 & 0,316 & 0,322 & 0,780 \\
\hline
\end{tabular}

Sumber: Data Penelitian, 2021

Kriteria validity dan reliabilitas juga dapat dilihat dari nilai reliabilitas suatu konstruk dan nilai average variance extracted ( $A V E$ ) dari masing-masing konstruk. Konstruk yang baik apabila memiliki nilai reliabilitas yang tinggi jika nilainya diatas 0,70 dan $A V E$ berada diatas 0,50 (Ghozali \& Latan 2015: 75). Berikut ini hasil pengujian composite reliability dan $A V E$ pada seluruh variabel adalah sebagai berikut. 
Tabel 3. Nilai Composite Reliability dan Average Variance Extracted (AVE)

\begin{tabular}{lllll}
\hline & $\begin{array}{l}\text { Cronbach's } \\
\text { Alpha }\end{array}$ & Rho_A & $\begin{array}{l}\text { Realibilitas } \\
\text { Komposit }\end{array}$ & AVE \\
\hline ADM & 0,708 & 1,775 & 0,836 & 0,724 \\
Efek Moderasi 1 & 1,000 & 1,000 & 1,000 & 1,000 \\
Efek Moderasi 2 & 1,000 & 1,000 & 1,000 & 1,000 \\
Efek Moderasi 3 & 1,000 & 1,000 & 1,000 & 1,000 \\
PBJ & 0,798 & 0,811 & 0,867 & 0,620 \\
PNRP & 0,756 & 0,788 & 0,858 & 0,671 \\
PRCN & 0,765 & 0,775 & 0,842 & 0,519 \\
SDM & 0,730 & 0,743 & 0,826 & 0,545 \\
\hline
\end{tabular}

Sumber: Data Penelitian, 2021

$R$-squares, merupakan koefisien determinasi pada konstruk endogen yang digunakan untuk melihat kemampuan variabel-variabel eksogen dalam menerangkan variabel endogen. Menurut Chin (1998) dalam Ghozali \& Latan (2015:78) nilai R-squares 0,67 (baik), 0,33 (moderat) dan 0,19 (lemah).

Tabel 4. Nilai R-Squares

\begin{tabular}{lll}
\hline & R Square & Adjusted R Square \\
\hline PNRP & 0,467 & 0,416 \\
\hline Sumber:
\end{tabular}

Sumber: Data Penelitian, 2021

Effect size ( $f$ square) dihitung sebagai nilai absolut kontribusi individual setiap variabel eksogen pada nilai $\mathrm{R}$-square variabel endogen. Predictive relevance $(\mathrm{Q}$ square) digunakan untuk mengukur seberapa baik nilai observasi dihasilkan oleh model dan juga estimasi parameternya atau mengetahui kapabilitas prediksi dengan prosedur blindfolding (Ghozali \& Latan 2015:81). Nilai Q square > 0, menunjukkan bahwa model memiiki predictive relevance, sedangkan $\mathrm{Q}$ square $<0$, menunjukkan bahwa model kurang memiliki predictive relevance (Ghozali dan Latan, 2015:81). Lebih lanjut Ghozali dan Latan (2015:80) menyebutkan bahwa dalam kaitannya dengan $\mathrm{f}$ square, perubahan $\mathrm{Q}$ square (q square) memberikan dampak relatif terhadap model struktural, dimana q square 0,02 (lemah), 0,15 (moderate) dan 0,35 (kuat).

Tabel 5. Nilai F square

\begin{tabular}{lll}
\hline & Variabel & \\
\hline ADM & 0,069 & \\
Efek Moderasi 1 & 0,001 & \\
Efek Moderasi 2 & 0,029 & \\
Efek Moderasi 3 & 0,014 & \\
PBJ & 0,163 \\
PRCN & 0,003 \\
SDM & 0,093 \\
\hline
\end{tabular}

Sumber: Data Penelitian, 2021

Nilai $Q^{2}$ predictive relevance diperoleh dari perhitungan sebagai berikut.

$\mathrm{Q}^{2}=1-\left(1-\mathrm{R}^{2}\right)$

$\mathrm{Q}^{2}=1-(1-0.467)$

$\mathrm{Q}^{2}=1-0,533=0,467$

Berdasarkan hasil perhitungan di atas diperoleh nilai Q2 predictive relevance sebesar 0,467 atau nilai Q2 predictive relevance $>0$ yang berarti model penelitian ini mempunyai predictive relevance. 
Hasil pengaruh jalur langsung dapat dilihat pada tabel path coefficient berikut ini.

Tabel 6. Path Coeffiicient

\begin{tabular}{lllllll}
\hline Hipotesis & $\begin{array}{l}\text { Pengaruh } \\
\text { Langsung }\end{array}$ & $\begin{array}{l}\text { Original } \\
\text { Sampel }\end{array}$ & $\begin{array}{l}\mathrm{t} \text { - } \\
\text { statistic }\end{array}$ & $\begin{array}{l}\mathrm{p}- \\
\text { value }\end{array}$ & \multicolumn{2}{c}{ Keterangan } \\
\hline $\mathrm{H}_{1}$ & PRCN $\rightarrow$ PNRP & 0,062 & 0,338 & 0,736 & Tidak signifikan & Ditolak \\
$\mathrm{H}_{2}$ & SDM $\rightarrow$ PNRP & 0,249 & 2,845 & 0,005 & Signifikan & Diterima \\
$\mathrm{H}_{3}$ & PBJ $\rightarrow$ PNRP & 0,445 & 2,533 & 0,012 & Signifikan & Diterima \\
$\mathrm{H}_{4}$ & Efek moderasi 1 & $-0,036$ & 0,210 & 0,834 & Tidak signifikan & Ditolak \\
$\mathrm{H}_{5}$ & Efek moderasi 2 & $-0,157$ & 1,089 & 0,277 & Tidak signifikan & Ditolak \\
$\mathrm{H}_{6}$ & Efek moderasi 3 & 0,158 & 0,804 & 0,422 & Tidak signifikan & Ditolak \\
\hline
\end{tabular}

Sumber: Data Penelitian, 2021

Hipotesis pertama tentang perencanaan anggaran berpengaruh negatif terhadap penyerapan anggaran, dimana hipotesis ditolak. Hasil penelitian ini mendukung penelitian yang dilakukan oleh (Salwah 2019), (Putri, 2014), dan (Rifai et al., 2016) yang menemukan bahwa penyerapan anggaran tidak dipengaruhi oleh perencanaan. Namun penelitian ini berbeda dengan penelitian yang dilakukan oleh (Zulaikah \& Burhany, 2019), (Hasni \& Basukianto, 2016), dan (Ramdhani \& Anisa, 2017) yang menunjukkan bahwa perencanaan berpengaruh positif terhadap penyerapan anggaran.

Hipotesis kedua tentang sumber daya manusia berpengaruh berpengaruh positif terhadap penyerapan anggaran, dimana hipotesis diterima. Hasil penelitian ini mendukung teori stewardship dimana sumber daya manusia atau pegawai pada perangkat daerah harus bekerja dengan baik dan mengutamakan kepentingan organisasi sehingga dapat mempercepat serapan anggaran. Hasil penelitian ini mendukung penelitian (Hasni \& Basukianto, 2016), (Ramdhani \& Anisa, 2017), namun bertolak belakang dengan penelitian yang dilakukan oleh (Ramadhani \& Setiawan, 2019) dan (Rifai et al., 2016) yang menyatakan bahwa sumber daya manusia tidak Mempengaruhi penyerapan anggaran.

Hipotesis ketiga tentang pengadaan barang/jasa berpengaruh positif terhadap penyerapan anggaran, dimana hipotesis diterima. Hasil penelitian ini mendukung teori stakeholder dimana pemerintah harus melaksanakan peranannya secara dua arah, baik bagi pemerintah sendiri maupun bagi masyarakat. Salah satu upaya pemerintah untuk memenuhi kebutuhan masyarakat adalah melalui pengadaan barang dan jasa. Penelitian ini mendukung penelitian yang dilakukan oleh (Tofani et al., 2020) dan (Hasni \& Basukianto, 2016). Sebaliknya, penelitian ini tidak sejalan dengan penelitian yang dilakukan oleh (Zulaikah \& Burhany, 2019) dan (Sanjaya, 2018) yang menemukan bahwa pengadaan barang/jasa tidak Mempengaruhi penyerapan anggaran.

Hipotesis Keempat tentang administrasi memperkuat perngaruh perencanaan terhadap penyerapan anggaran, dimana hipotesis ditolak. Hasil penelitian ini tidak sejalan dengan teori signalling yang menjelaskan bahwa pemerintah akan memberikan sinyal terkait perencanaan yang akan direalisasikan kepada masyarakat. Administrasi yang baik menunjukkan bahwa pemerintah daerah telah menjalankan amanah masyarakat dengan baik, namun administrasi tidak mampu memperkuat hubungan antara perencanaan dengan penyerapan anggaran. 
Hipotesis Kelima tentang administrasi memperkuat perngaruh sumber daya manusia terhadap penyerapan anggaran, dimana hipotesis ditolak. Menurut teori signalling, pemerintah daerah harus segera menyampaikan sinyal atau informasi terkait administrasi dalam organisasi agar sumber daya manusia yang ada dapat segera menyelesaikan tugas yang tersedia demi kepentingan masyarakat. Namun hasil penelitian ini tidak mendukung teori signalling, karena administrasi dalam penelitian ini tidak dapat memperkuat hubungan antara sumber daya manusia dengan penyerapan anggaran.

Hipotesis Keenam tentang administrasi memperkuat perngaruh pengadaan barang/jasa terhadap penyerapan anggaran, dimana hipotesis ditolak. Berdasarkan teori stewardhsip, dimana pengadaan barang/jasa harus dilakukan oleh panitia pengadaan yang tepat agar dapat melaksanakan tugasnya dengan baik untuk kepentingan bersama tidak mengutamakan kepentingan individu, sehingga dibutuhkan administrasi yang baik seperti proses penetapan panitia pengadaan. Namun hasil penelitian ini tidak mendukung teori stewardhsip, karena administrasi dalam penelitian ini tidak dapat memperkuat hubungan antara pengadaan barang/jasa dengan penyerapan anggaran.

Pengujian efek moderasi dalam PLS digunakan untuk menunjukkan interaksi antara variabel eksogen (prediktor) dengan variabel moderator dalam mempengaruhi variabel endogen (Ghozali \& Latan, 2015:163). Ada empat jenis efek moderasi yang ditimbulkan dari hubungan moderasi yaitu pure moderasi, quasi moderasi, homologiser moderasi dan predictor moderasi (Solimun, 2011).

Tabel 7. Total effect

\begin{tabular}{|c|c|c|c|c|c|c|}
\hline \multirow[t]{2}{*}{ Hipotesis } & Pengaruh & Original & & p- & \multicolumn{2}{|c|}{ Keterangan } \\
\hline & $\mathrm{ADM} \rightarrow \mathrm{PNRP}$ & 0,203 & 1,961 & 0,050 & & \\
\hline $\mathrm{H} 4$ & Efek moderasi 1 & $-0,036$ & 0,210 & 0,834 & $\begin{array}{l}\text { Tidak } \\
\text { signifikan }\end{array}$ & Pure moderasi \\
\hline H5 & Efek moderasi 2 & $-0,157$ & 1,089 & 0,277 & $\begin{array}{l}\text { Tidak } \\
\text { signifikan }\end{array}$ & Pure moderasi \\
\hline H6 & Efek moderasi 3 & 0,158 & 0,804 & 0,422 & $\begin{array}{l}\text { Tidak } \\
\text { signifikan }\end{array}$ & Pure moderasi \\
\hline
\end{tabular}

Sumber: Data Penelitian, 2021

Temuan dari penelitian ini dapat memperjelas konsep teori stewardship bahwa pemerintah daerah harus mementingkan kepentingan organisasi dan masyarakat daripada kepentingan individu. Dapat juga memperjelas teori signalling bahwa pemerintah daerah harus senantiasa memberikan informasi atau sinyal kepada masyarakat mengenai serapan anggaran yang teah dilaksanakan, agar masyarakat terus mendukung pemerintahan yang sedang berjalan. Sedangkan, teori stakeholder dalam penelitian ini memperjelas bahwa pemerintah daerah harus melaksanakan peranannya secara dua arah untuk memenuhi kebutuhan pemerintahan sendiri maupun stakeholder lainnya. Hasil penelitian ini dapat dijadikan sebagai bahan pertimbangan dan masukan bagi para pembuat kebijakan terutama berkaitan dengan APBD terhadap pembuatan/perbaikan regulasi-regulasi yang diterapkan yang akan digunakan oleh para SKPD terkait penyerapan anggaran seperti Peraturan Daerah Kabupaten Sumbawa Nomor 18 Tahun 2007 Tentang Pokok-Pokok Pengelolaan Keuangan Daerah. Para SKPD 
dapat memberikan kontribusi dalam pengelolaan APBD untuk meningkatkan perekonomian daerah.

\section{SIMPULAN}

Perencanaan tidak berpengaruh secara signifikan terhadap penyerapan anggaran. Sumber daya manusia berpengaruh positif dan signifikan terhadap penyerapan anggaran. Pengadaan barang/jasa berpengaruh positif dan signifikan terhadap penyerapan anggaran. Administrasi tidak berpengaruh secara signifikan terhadap hubungan perencanaan dengan penyerapan anggaran. Administrasi tidak berpengaruh secara signifikan terhadap hubungan sumber daya manusia dengan penyerapan anggaran. Administrasi tidak berpengaruh secara signifikan terhadap hubungan pengadaan barang/jasa dengan penyerapan anggaran.

Disarankan bagi satuan kerja perangkat Daerah Kabupaten Sumbawa agar dapat meningkatkan kualitas sumber daya manusia dan pengadaan barang/jasa, serta melakukan perbaikan terhadap perencanaan dan administrasi agar dapat mempercepat tingkat penyerapan anggaran belanja dan sesuai dengan target yang telah ditentukan. Sedangkan untuk penelitian selanjutnya dapat menambahkan variabel lain yang memiliki keterkaitan dengan Penyerapan Anggaran seperti pelaksanaan anggaran, regulasi, pemanfaatan teknologi informasi, dan beban kerja.

Kemudian indikator dan pernyataan pada kuesioner dalam penelitian ini dianggap masih belum cukup menggambarkan dengan jelas pendapat responden terhadap variabel yang diteliti. Sehingga diharapkan untuk penelitian selanjutnya dapat memperluas lagi indikator dan pernyataan dalam kuesioner agar dapat memperjelas pendapat dari responden, atau bila perlu pada kuesioner disediakan sebuah kolom tersendiri agar responden dapat menuliskan penjelasan dari jawaban mereka.

\section{REFERENSI}

Alimuddin. (2018). Analisis Penyerapan Anggaran di Perguruan Tinggi Negeri (PTN) dan Kopertis Makassar. Universitas Hasanuddin.

Anfujatin. (2016). Analisis Faktor-Faktor yang Menyebabkan Rendahnya Penyerapan Anggaran Belanja pada SKPD Kabupaten Tuban. Jurnal Administrasi Publik, Vol.14(No. 1), 1-16.

Cace, C., Cace, S., \& Nicolaescu, V. (2011). Absorption Of The Structural Funds In Romania. Journal for Economic Forecasting, 1(2), 84-105.

Dewi1, N. L. P. L., Dwirandra, A. A. N. B., \& Wirakusuma3, M. G. (2017). Penyerapan Anggaran Pemerintah Kabupaten Tabanan. E-Jurnal Ekonomi Dan Bisnis Universitas Udayana, 6(4), 1609-1638.

Endang Suwarni, D., \& Farid Maruf, M. (2018). Faktor-Faktor Yang Mempengaruhi Keterlambatan Penyerapan Anggaran Pendapatan Dan Belanja Daerah (APBD) Di Kota Surabaya (Studi pada SKPD Dinas PU Bina Marga dan Pematusan). Publika, 6(5), 1-7.

Ghozali, I., \& Latan, H. (2015). Partial Least Square: Konsep, Teknik dan Aplikasi Menggunakan Program SmartPLS 3.0. Badan Penerbit Universitas Diponegoro. 
Goddard, A., \& Mkasiwa, T. A. (2016). New Public Management and Budgeting Practices in Tanzanian Central Government: 'Struggling for Conformance.' Journal of Accounting in Emerging Economies, 6(4), 340-371.

Harahap, S. A. S., Taufik, T., \& Nurazlina. (2020). Pengaruh Perencanaan Anggaran, Pelaksanaan anggaran, Pencatatan Administrasi dan Kompetensi Sumber Daya Manusia Terhadap Tingkat Penyerapan Anggaran ( Studi Empiris pada OPD Kota Dumai ). Akuntansi Keuangan Dan Bisnis, 13(1), 1-10.

Hartono, J. (2014). Metode Penelitian Bisnis, Salah Kaprah dan Pengalaman-pengalaman (Edisi Keen). BPFE.

Hasni, N. T., \& Basukianto. (2016). Analisis Faktor-Faktor Yang Mempengaruhi Penyerapan Anggaran Pada Pemerintah Daerah Kabupaten Batang. Jurnal Akuntansi, 13(1), 33-44.

Iqbal, M. (2018). Pengaruh Perencanaan Anggaran Dan Kompetensi Sumber Daya Manusia Terhadap Penyerapan Anggaran Dengan Komitmen Organisasi Sebagai Pemoderasi. Universitas Hasanuddin Makassar.

Putri, C. T. (2014). Analisis Faktor-Faktor yang Mempengaruhi Penyerapan Anggaran pada Satuan Kerja Perangkat Daerah di Pemerintah Provinsi Bengkulu.

Ramadhani, R., \& Setiawan, M. A. (2019). Pengaruh regulasi, politik anggaran, perencanaan anggaran, sumber daya manusia dan pengadaan barang/ jasa terhadap penyerapan anggaran belanja pada opd provinsi sumatera barat. Jurnal Eksplorasi Akuntansi, 1(2), 710-726.

Ramdhani, D., \& Anisa, I. Z. (2017). Pengaruh Perencanaan Anggaran, Kualitas Sumber Daya Manusia dan Pelaksanaan Anggaran. Jurnal Riser Akuntansi Terpadu, 10(1), 134-148.

Renoat, R. E., \& Latupeirissa, D. S. (2020). Pengaruh Variabel Perencanaan Anggaran, Administrasi dan Kompetensi Sumber Daya Manusia terhadap Penyerapan Anggaran. Jurnal Bisnis Dan Manajemen, 4(2), 23-32.

Rifai, A., Inapty, B. A., \& Pancawati M., R. S. (2016). Analisis Faktor-Faktor Yang Memengaruhi Keterlambatan Daya Serap Anggaran (Studi Empiris Pada SKPD Pemprov NTB). Jurnal Ilmiah Akuntansi Dan Bisnis, 1-10.

Salwah, A. (2019). Pengaruh perencanaan Anggaran Dan Pelaksanaan Anggaran Terhadap Serapan Anggaran Satuan Kerja Perangkat Daerah (SKPD) Pada Pemerintah Kota Banda Aceh. Jurnal Transformasi Administrasi, 9(2), 164-182.

Sanjaya, T. (2018). Pengaruh Regulasi Keuangan Daerah, Politik Anggaran Dan Pelaksanaan Pengadaan Barang/Jasa Terhadap Penyerapan Anggaran Pada OPD Provinsi Sumatera Barat. Akuntansi, 2(4), 2-9.

Sugiyono. (2013). Metode Penelitian Pendidikan Pendekatan Kuantitatif, Kualitatif dan $R \mathcal{E D}$. Alfabeta.

Thomas, N. I. (2018). Factors Influencing Absorption Of Budgeted Funds In The Kenyan Public Sector. Journal of Accounting in Emerging Economies, 2(2), 121.

Tofani, M. I., Hasan, A., \& Nasrizal. (2020). Analysis Of The Factors That Affects The Budget Absorption In The Riau And Kepri Supreme Courts With Organisational Commitments As The Moderating Factor. Jurnal Ilmiah Akuntansi, 4(2), 165-182.

Yanuriza, Hasan, A., \& M.Rasuli. (2019). Pengaruh Perencanaan Anggaran , Pencatatan Administrasi , Sumberdaya Manusia , Komitmen Organisasi dan Lingkungan Birokrasi terhadap Penyerapan Anggaran PNBP Kegiatan 
Pengamanan Objek Vital pada Satker Jajaran Polda Riau. Jurnal Ekonomi, 27(4), 409-423.

Zulaikah, B., \& Burhany, D. I. (2019). Faktor-Faktor Yang Mempengaruhi Penumpukan Penyerapan Anggaran Pada Triwulan Iv Di Kota Cimahi. Jurnal Akuntansi, Keuangan, Dan Audit, 3(4), 1221-1234. 